\title{
Mean Platelet Volume, Neutrophil Lymphocyte Ratio and Platelet Lymphocyte Ratio to Predict Complications During Postoperative Recovery of High Risk Surgical Patients
}

\author{
Postoperatif Yoğun Bakım Ünitesinde Takip Edilen Olgularda \\ Komplikasyon Gelişimi ile Kan Parametreleri Arasındaki İlişkinin \\ Değerlendirilmesi
}

\section{(D) Bedih Balkan1, (D Mustafa Çelik², (D) Büşra Tok Çekmecelioğlu1, (D) Damla Yavuz³, (D) Dilek Altun4, (D) Gülsüm Oya Hergünsel ${ }^{3}$}

${ }^{1}$ University of Health Sciences Turkey, Mehmet Akif Ersoy Thoracic and Cardiovascular Surgery Training and Research Hospital, Clinic of Anesthesiology and Reanimation, İstanbul, Turkey

${ }^{2}$ University of Health Sciences Turkey, İstanbul Bakırköy Dr. Sadi Konuk Training and Research Hospital, Clinic of Otorhinolaryngology-Head and Neck Surgery, İstanbul, Turkey

${ }^{3}$ University of Health Sciences Turkey, İstanbul Bakırköy Dr. Sadi Konuk Training and Research Hospital, Clinic of Anesthesiology and Reanimation, İstanbul, Turkey

4Acıbadem Mehmet Ali Aydınlar University Vocational School of Health Services, Clinic of Anesthesiology and Reanimation, İstanbul, Turkey

\section{Abstract}

Objective: This study sought to define the correlation between the occurrence of the complications and certain blood parameters in high risk surgical patients who were monitored for 24 hours in the intensive care unit postoperatively.

Method: Two hundred-fifty seven cases (126 females 131 males; mean age 42.18 \pm 8.54 years; range 19-73 years) who were operated on in our hospital and followed up in the intensive care unit for 24 hours were included in this study. The files of all cases included demographic characteristics, erythrocyte count (RBC), leukocyte count (WBC), platelet count (PLT), mean platelet volume (MPV), neutrophil, lymphocyte, neutrophil/lymphocyte ratio (NLR), platelet/lymphocyte ratio (PLR), serum blood urea nitrogen (BUN) and creatinine values. Group A consisted of cases that did not develop complications in the first 24 hours, and group B consisted of cases that developed complications in the first 24 hours postoperatively. The blood hemogram parameters RBC, WBC, PLT, MPV, NLO, PLO, and the biochemistry parameters BUN and creatinine were compared between the groups.

\section{Öz}

\begin{abstract}
Amaç: Bu çalışmada, elektif şartlarda opere edilen ve postoperatif 24 saat boyunca yoğun bakım ünitesinde takip edilen olgularda komplikasyon gelişimi ile kan parametreleri arasındaki ilişki araştırıldı.

Yöntem: Bu çalışmaya, hastanemizde ameliyat edilip, 24 saat postoperatif yoğun bakımda takip edilen 257 olgu (126 kadın 131 erkek; ortalama yaş 42,18 $\pm 8,54$ yıl; aralık 19-73 yıl) dahil edildi. Tüm olguların dosyaları demografik özellikleri, eritrosit sayısı (RBC), lökosit sayısı (WBC), trombosit sayısı (PLT), ortalama trombosit hacmi (MPV), nötrofil, lenfosit, nötrofil/lenfosit oranı (NLO), trombosit/lenfosit oranı (PLO), serum kan üre azotu (BUN) ve kreatinin değerleri açısından değerlendirildi. Grup A postoperatif ilk 24 saatte komplikasyon gelişmeyen olgulardan, grup B postoperatif ilk 24 saatte komplikasyon gelişen olgulardan oluşmakta idi. Gruplar arasında kan hemogram parametrelerinden RBC, WBC, PLT, MPV, NLO, PLO, biyokimya parametrelerinden BUN ve kreatinin değerleri karşılaştırıldı.
\end{abstract}

Bulgular: Grup B'de preoperatif MPV değeri ve postoperatif MPV değeri grup A'dan anlamlı olarak daha yüksekti ( $p$-değerleri sırasıyla 0,038 ve

Address for Correspondence: Bedih Balkan, University of Health Sciences Turkey, Mehmet Akif Ersoy Thoracic and Cardiovascular Surgery Training and Research Hospital, Clinic of Anesthesiology and Reanimation, ìstanbul, Turkey

E-mail: drbedihbalkan21@gmail.com ORCID: orcid.org/0000-0003-3510-6991 Received: 23.04.2021 Accepted: 03.11 .2021

Cite this article as: Balkan B, Çelik M, Tok Çekmecelioğlu B, Yavuz D, Altun D, Hergünsel GO. Mean Platelet Volume, Neutrophil Lymphocyte Ratio and Platelet Lymphocyte Ratio to Predict Complications During Postoperative Recovery of High Risk Surgical Patients. Bagcilar Med Bull 2021;6(4):382-389 (C) Copyright 2021 by the Health Sciences University Turkey, Bagcilar Training and Research Hospital Bagcilar Medical Bulletin published by Galenos Publishing House. 


\section{Abstract}

Results: Preoperative MPV value and postoperative MPV value were significantly higher in group $B$ than group $A$ ( $p$-values 0.038 and 0.045 , respectively). In groups $A$ and $B$, the postoperative MPV value increased significantly compared to the preoperative period $(p=0.032, p=0.000$, respectively). Preoperative PLR and postoperative PLR values did not differ significantly in groups $A$ and $B(p=0.101$ and $p=0.458$, respectively). The postoperative PLR value increased significantly in groups $A$ and $B$ compared to the preoperative period ( $p=0.000$ and $p=0.047$, respectively) Preoperative and postoperative NLR values in group $B$ were significantly higher than group $A$ ( $p=0.006$ and $p=0.025$ respectively). In groups $A$ and $B$, the postoperative NLR value increased significantly compared to the preoperative period ( $p=0.000$ and $p=0.006$, respectively).

Conclusion: In this study, the cases that developed complications had more significant increases in their MPV, NLR, and PLR values during the postoperative period than their counterparts who experienced no complications.

Keywords: ASA-3 cases, complication, intensive care, mean platelet volume, neutrophil-lymphocyte ratio, platelet-lymphocyte ratio

\section{Öz}

0,045). Grup A ve B'de postoperatif MPV değeri preoperatif döneme göre anlamlı artış göstermiştir (sırasıyla $p=0,032, p=0,000$ ). Grup A ve $B^{\prime}$ de preoperatif PLO değeri ve postoperatif PLO değeri anlamlı farklıık göstermemiş̧tir (sırasıyla $p=0,101$ ve $p=0,458$ ). Grup A ve B'de postoperatif PLO değeri preoperatif döneme göre anlamlı artış göstermiştir (sırasıyla $p=0,000$ ve $p=0,047$ ) grup B'de preoperatif ve postoperatif NLO değeri grup A'dan anlamlı olarak daha yüksekti (sırasıyla $p=0,006$ ve $p=0,025$ ). Grup A ve B'de postoperatif NLO değeri preoperatif döneme göre anlamlı artış göstermiştir (sırasıyla $p=0,000$ ve $p=0,006$ ).

Sonuç: Bu çalışmada, komplikasyon gelişen olgularda MPV, NLO ve PLO değerlerinin postoperatif dönemde daha fazla arttığı izlendi. MPV, NLO ve PLO gibi basit, hızlı ve ucuz bir teknikle yoğun bakım ünitesinde takip edilen olgularda gelişebilecek komplikasyonlar hakkında öngörü sağlanması, şüphesiz mortalite oranını azaltacaktır.

Anahtar kelimeler: ASA-3 hastalar, komplikasyon, nötrofil/lenfosit oranı, ortalama trombosit hacmi, trombosit/lenfosit oranı, yoğun bakım

Current research indicates that any variation in specific blood parameters impacts the complication occurrence and mortality of various diseases. Many studies in the literature have evaluated the correlation between mortality and blood parameters of cases monitored in the ICU (58). However, few have assessed the relationship between the occurrence of complications and changes in blood parameters for patients followed in the ICU. Therefore, this study sought to define the correlation between occurrence of the complications and certain blood parameters in high risk surgical patients who had undergone elective surgery and were monitored for 24 hours in the ICU postoperatively.

\section{Materials and Methods}

Approval for the study was granted by the Hospital Ethics Committee (University of Health Sciences Turkey, İstanbul Bakırköy Dr. Sadi Konuk Training and Research Hospital Ethics Committee no: 2017-154). A list was drawn up in the preoperative assessment of all patients classified as American Society of Anesthesiologists classification 3-4, who might require postoperative intensive care. They were then admitted and followed up in the ICU after elective otolaryngology, general surgery, orthopedic, thoracic, brain, and urology operations between June 2016 and June 2017. This study was completed under the Declaration of Helsinki principles and best clinical practice guidelines. A retrospective review was made of collected data of the patients who underwent elective surgery and were treated at least for 24 hours in the ICU. The medical probability of complications linked to surgical procedures. 
charts for all these patients were reviewed. Data were collected by a researcher using a standardized case report form, including the hemogram and biochemistry values checked in the preoperative anesthesia outpatient clinic (or preoperatively if the anesthesia outpatient clinic duration has been prolonged) and the day after the postoperative surgery, since there were elective cases. The data recorded included hemodynamics heart rate, systolic blood pressure, diastolic blood pressure, and mean blood pressure, oxygen saturation measured via pulse oximetry, duration of mechanical ventilation, and length of stay in the ICU.

The demographic information of the patients was retrieved from the hospital records system.

The study included cases aged $\geq 18$ years, operated on under elective conditions, were monitored for 24 hours or more in the ICU postoperatively and were discharged while being stable.

Considering the exclusion criteria, cases aged $<18$ years, those who died, underwent emergency surgery, had a history of operation, and had any hematological disease were excluded from the study.

The files of all cases were assessed in terms of demographic characteristics, erythrocyte count (RBC), leukocyte count (WBC), platelet count (PLT), mean platelet volume (MPV), neutrophil count, lymphocyte count, neutrophillymphocyte ratio (NLR), platelet-lymphocyte ratio (PLR), BUN and serum creatinine values. The values were recorded preoperatively and 24 hours after surgery for all the cases in the study.

The cases were separated into two groups considering the occurrence of complications in the first 24 hours postoperatively. Group A comprised of cases who did not have any complications, and group B involved cases that developed complications in the first 24 hours postoperatively.

Postoperative complications that were accepted were as follows;

- Cardiac complications; ventricular tachycardia, angina, atrial fibrillation (AF), myocardial infarction (MI),

- Pulmonary complications; pneumonia, pneumothorax, pulmonary embolism, pleural effusion

- Neurological complications; stroke, cerebrovascular ischemia, hemorrhage, transient ischemic attack

- Renal complications; acute renal failure (accepted as serum creatinine values $>2.0 \mathrm{mg} / \mathrm{dL}$ or $50 \%$ increase compared to preoperative values) and electrolyte disorder require hemodialysis.

- Infection complications; sepsis, systemic inflammatory response syndrome, deep or superficial sternal tissue infections.

The groups were compared in terms of the blood parameters of RBC, WBC, PLT, MPV, NLR, PLR, BUN, and creatinine values.

\section{Statistical Analysis}

Data obtained in the study were analyzed statistically using NCSS 2007 software (Number Cruncher Statistical System, Kaysville, Utah, USA). Descriptive statistics were stated as mean, standard deviation, median, minimum and maximum values, or frequency and percentage. Independent quantitative data were analyzed with the Independent Samples t-test and Mann-Whitney U test. Dependent quantitative data were analyzed using the Friedman test and Wilcoxon test. In the analysis of independent qualitative data, the chi-square test was applied. A value of $\mathrm{p}<0.05$ was accepted as statistically significant.

\section{Results}

Patient characteristics: This study included 257 cases (126 female, 131 male) followed up after elective surgeries for 48 hours in the ICU. The demographic characteristics of the cases included in the study are given in Table 1. Surgery types and anesthesia data are summarized in Table 2.

Clinical outcomes: In group B (46 patients), the preoperative and postoperative $\mathrm{RBC}$ values were significantly lower compared to those of group A (211 patients) ( $\mathrm{p}=0.006$, $\mathrm{p}=0.002$, respectively). There was a significant fall in postoperative $\mathrm{RBC}$ values in both groups compared to the preoperative values (group A: $\mathrm{p}=0.000$, group $\mathrm{B}$ : $\mathrm{p}=0.000$ )

\begin{tabular}{lll}
\multicolumn{3}{l}{ Table 1. Demographic data of the patients } \\
\cline { 2 - 3 } & Group A ( $\mathbf{n = 2 1 1 )}$ & Group B ( $\mathbf{n = 4 6 )}$ \\
\hline Age (years) & $40.46 \pm 12.40(19-68)$ & $46.28 \pm 15.18(30-73)$ \\
Male (n) & $118(55.92 \%)$ & $24(52.18 \%)$ \\
Female (n) & $93(44.08 \%)$ & $22(47.82 \%)$ \\
& & Cardiac: $17(36.96 \%)$ \\
& & Infection: $11(23.91 \%)$ \\
& & Pulmonary: 11 \\
Complications & None & $(23.91 \%)$ \\
& & Neurological: 6 \\
& & $(13.04 \%)$ \\
& & Renal: $1(2.18 \%)$
\end{tabular}


Table 2. Surgery types and anesthesia data of patients

Otolaryngological operations $(n=63)$

- Transoral robotic surgery for obstructive sleep apnea syndrome (16)

- Uvulopalatopharyngoplasty (21)

- Superficial parotidectomy (11)

- Total parotidectomy (9)

- Tympanomastoidectomy (5)

Urology operations $(n=38)$

- Transurethral resection of the prostate (18)

- Robotic prostatectomy (12)

- Partial nephrectomy (8)

Thoracic surgery $(n=27)$

- Lung cancer surgery (13)

- Surgery for chest wall tumors (6)

- Surgery for lung and respiratory infection (8)

There were no significant differences in preoperative and postoperative WBC values in groups A and $B(p>0.05)$. The postoperative $W B C$ amount was significantly increased compared to the preoperative values in group $\mathrm{A}$ and $\mathrm{B}$ ( $\mathrm{p}=0.000, \mathrm{p}=0.030$, respectively).

In groups $\mathrm{A}$ and $\mathrm{B}$, there was no significant difference in preoperative and postoperative PLT values ( $p>0.05$ ). The postoperative PLT values in group A and B were significantly lower compared to the preoperative value $(\mathrm{p}=0.000, \mathrm{p}=0.005$, respectively).

The preoperative and postoperative MPV values in group B were significantly higher than those of group A ( $\mathrm{p}=0.038$, $\mathrm{p}=0.045$, respectively). In group $\mathrm{B}$, the postoperative MPV value was significantly increased compared to the preoperative value $(\mathrm{p}=0.032)$. The postoperative MPV value in group A was also significantly increased compared to the preoperative value $(\mathrm{p}=0.000)$.

In group $\mathrm{B}$, the preoperative neutrophil value was significantly higher than that of group $A(p=0.020)$. In groups $\mathrm{A}$ and $\mathrm{B}$, the postoperative neutrophil values were not significantly different $(\mathrm{p}>0.005)$. The postoperative neutrophil values in groups A and B were significantly increased compared to the preoperative values $(\mathrm{p}=0.000$ for both).

In group B, the preoperative lymphocyte and postoperative lymphocyte values were significantly lower than those of group A ( $\mathrm{p}=0.005, \mathrm{p}=0.018$, respectively). The postoperative lymphocyte values in groups $A$ and $B$ fell significantly compared to the preoperative values ( $\mathrm{p}<0.05$ for both).

In groups $\mathrm{A}$ and $\mathrm{B}$, the preoperative $\mathrm{BUN}$ values did not significantly differ $(p>0.005)$. In group $B$, the postoperative BUN value was significantly higher than that of group A
General surgery operations $(n=56)$

- Colorectal surgeries (26)

- Total thyroidectomy (8)

- Bariatric surgery (22)

Orthopedic operations $(n=35)$

- Knee, elbow, hip, shoulder, foot and ankle (10)

- Multipl injuries (25)

Brain operations $(n=37)$

- Brain tumors (22)

- Subarachnoid hemorrhage (15)
( $\mathrm{p}=0.006$ ). The postoperative BUN value in group B was not significantly different from the preoperative value $(p>0.005)$. The postoperative BUN value in group A was significantly increased compared to the preoperative value $(\mathrm{p}=0.012)$.

In groups $A$ and $B$, the preoperative creatinine values were not significantly different $(\mathrm{p}>0.005)$. The postoperative creatinine value in group $B$ was significantly higher compared to that of group $A(p=0.026)$. In group $B$, the postoperative creatinine value showed a significant increase compared to the preoperative value $(\mathrm{p}=0.047)$. The postoperative creatinine value in group A was not significantly increased than the preoperative value ( $>>0.005)$.

No significant differences were determined between groups A and B regarding preoperative and postoperative PLR values ( $\mathrm{p}=0.101$ and $\mathrm{p}=0.458$, respectively). The postoperative PLR values in groups A and B were significantly increased compared to the preoperative values $(\mathrm{p}=0.000$ and $\mathrm{p}=0.047$, respectively).

In group B, the preoperative and postoperative NLR values were significantly higher compared to those of group A ( $\mathrm{p}=0.006$ and $\mathrm{p}=0.025$, respectively). The postoperative NLR values in groups A and B were significantly increased compared to the preoperative values $(\mathrm{p}=0.000$ and $\mathrm{p}=0.006$, respectively) (Table 3 ).

\section{Discussion}

In this retrospective study, the correlation was evaluated between complication occurrence and blood parameters of high risk patients operated under elective conditions and monitored for 24 hours postoperatively in the ICU. 
Table 3. Comparison of preoperative and postoperative blood values in the groups

\begin{tabular}{|c|c|c|c|c|c|c|}
\hline & \multicolumn{2}{|c|}{ Group A } & \multicolumn{2}{|c|}{ Group B } & \multirow[t]{2}{*}{ p } & \\
\hline & Mean \pm SD & Median & Mean \pm SD & Median & & \\
\hline \multicolumn{7}{|l|}{$\operatorname{RBC}\left(10^{6} / \mu \mathrm{L}\right)$} \\
\hline Preoperative & $4.4 \pm 0.9$ & 4.6 & $4.1 \pm 0.7$ & 4.2 & 0.006 & $\mathrm{~m}$ \\
\hline Postoperative & $3.9 \pm 0.8$ & 3.9 & $3.5 \pm 0.7$ & 3.6 & 0.002 & $\mathrm{~m}$ \\
\hline Variation $p$ & 0.000 & w & 0.000 & w & & \\
\hline \multicolumn{7}{|l|}{ WBC $\left(10^{3} / \mu L\right)$} \\
\hline Preoperative & $9.9 \pm 4.4$ & 9.0 & $11.8 \pm 6.5$ & 10.5 & 0.111 & $\mathrm{~m}$ \\
\hline Postoperative & $12.5 \pm 5.0$ & 12.3 & $14.4 \pm 9.1$ & 12.2 & 0.487 & $\mathrm{~m}$ \\
\hline $\begin{array}{l}\text { Variation p } \\
\text { PLT }\left(10^{3} / \mu L\right)\end{array}$ & 0.000 & w & 0.030 & w & & \\
\hline Preoperative & $244.9 \pm 99.1$ & 234.4 & $241.7 \pm 134.8$ & 216.1 & 0.207 & $\mathrm{~m}$ \\
\hline Postoperative & $215.7 \pm 95.4$ & 206.4 & $214.3 \pm 140.9$ & 187.0 & 0.169 & $\mathrm{~m}$ \\
\hline Variation p & 0.000 & w & 0.005 & w & & \\
\hline \multicolumn{7}{|l|}{ MPV (fL) } \\
\hline Preoperative & $8.0 \pm 1.5$ & 7.7 & $8.5 \pm 1.6$ & 8.2 & 0.038 & $\mathrm{~m}$ \\
\hline Postoperative & $8.3 \pm 1.7$ & 8.0 & $8.8 \pm 1.7$ & 8.6 & 0.045 & $\mathrm{~m}$ \\
\hline Variation $p$ & 0.000 & w & 0.032 & w & & \\
\hline \multicolumn{7}{|l|}{ Neutrophil (\%) } \\
\hline Preoperative & $66.4 \pm 15.5$ & 66.3 & $72.1 \pm 14.2$ & 73.4 & 0.020 & $\mathrm{~m}$ \\
\hline Postoperative & $80.2 \pm 11.6$ & 82.9 & $83.2 \pm 6.7$ & 84.1 & 0.186 & $\mathrm{~m}$ \\
\hline Variation $p$ & 0.000 & w & 0.000 & w & & \\
\hline \multicolumn{7}{|c|}{ Lymphocyte (\%) } \\
\hline Preoperative & $22.5 \pm 12.8$ & 22.3 & $16.7 \pm 11.1$ & 15.3 & 0.005 & $\mathrm{~m}$ \\
\hline Postoperative & $11.6 \pm 9.0$ & 9.6 & $10.0 \pm 11.1$ & 7.2 & 0.018 & $\mathrm{~m}$ \\
\hline Variation $p$ & 0.000 & w & 0.001 & w & & \\
\hline \multicolumn{7}{|l|}{ BUN (mg/dL) } \\
\hline Preoperative & $42.8 \pm 30.2$ & 34.0 & $50.1 \pm 33.9$ & 38.5 & 0.122 & $\mathrm{~m}$ \\
\hline Postoperative & $42.7 \pm 29.9$ & 34.0 & $58.7 \pm 37.7$ & 45.0 & 0.006 & $\mathrm{~m}$ \\
\hline Variation $p$ & 0.550 & w & 0.012 & w & & \\
\hline \multicolumn{7}{|c|}{ Creatinine (mg/dL) } \\
\hline Preoperative & $1.1 \pm 1.0$ & 0.9 & $1.1 \pm 0.6$ & 1.0 & 0.402 & $\mathrm{~m}$ \\
\hline Postoperative & $1.3 \pm 1.4$ & 0.8 & $1.4 \pm 1.0$ & 1.0 & 0.026 & $\mathrm{~m}$ \\
\hline Variation $\mathrm{p}$ & 0.412 & w & 0.047 & w & & \\
\hline \multicolumn{7}{|c|}{ PLT/lymphocyte (\%) } \\
\hline Preoperative & $18.8 \pm 21.8$ & 10.5 & $28.6 \pm 37.3$ & 12.1 & 0.101 & $\mathrm{~m}$ \\
\hline Postoperative & $27.9 \pm 29.7$ & 20.7 & $36.4 \pm 42.3$ & 23.5 & 0.458 & $\mathrm{~m}$ \\
\hline Variation $\mathrm{p}$ & 0.000 & w & 0.047 & w & & \\
\hline \multicolumn{7}{|c|}{ Neutrophil/lymphocyte (\%) } \\
\hline Preoperative & $5.8 \pm 7.9$ & 2.9 & $8.8 \pm 8.8$ & 4.4 & 0.006 & $\mathrm{~m}$ \\
\hline Postoperative & $10.7 \pm 8.7$ & 8.6 & $13.3 \pm 9.3$ & 11.9 & 0.025 & $\mathrm{~m}$ \\
\hline Variation $\mathrm{p}$ & 0.000 & & 0.006 & & & \\
\hline
\end{tabular}

SD: Standard deviation, BUN: Blood urea nitrogen, PLT: Platelet count, MPV: Mean platelet volume, WBC: Leukocyte count, RBC: Erythrocyte count

Statistically significant values were shown as bold characters 
In the cases with complications, the blood parameters of MPV, NLR, and PLR were higher in the postoperative period. The elevation of MPV, NLR, and PLR, especially in cases with complications, showed the role of the inflammatory response in the occurrence of complications.

ICUs are the units where cases are closely monitored for surgical complications. Knowing the factors that affect the occurrence of complications is very important for clinicians working in ICUs to comprehend the seriousness of the situation. An estimation of complications beforehand and taking necessary precautions will both reduce mortality and prevent long hospital stays. Identifying and preventing complications before they occur is clear, considering that patient care in ICUs is costly and creates a greater economic burden.

Current researches have focused on high mortality in ICUs, and cause-effect studies have an important place in the literature. There are very few studies in the literature on the prediction of complications in ICUs. The current study researched whether the blood parameters of MPV, NLR, and PLR primarily had predictive value for the occurrence of complications in cases monitored in the postoperative ICU. To the best of our knowledge, this is the first study related to this topic in the literature. The study included cases operated under elective conditions and monitored in the ICU. Cases were separated into two groups as those who had and did not have complications, and the correlation with blood parameters was assessed.

The chemical and physical properties of platelets are related to size. The increase in MPV is a new parameter used as a cardiovascular risk factor. MPV is an important parameter showing the activation and function of platelets, and activated platelets are known to play an important role in systemic inflammatory response syndrome the pathogenesis of atherothrombosis. Studies have shown that in the occurrence of atherothrombosis, not only the platelet content but also the material released from platelets plays an effective role in the induction of inflammation (5).

In vitro studies have shown that parameters such as p-selectin, active glycoprotein $2 \mathrm{~b} / 3 \mathrm{a}$, platelet factor 4 , and beta-thromboglobulin play a role in platelet activation and functions. However, these parameters are not studied in routine applications because of the need for detailed equipment and expertise and the relatively higher expense, so they are not used to assess platelet activation and functions. Examining MPV is a simple, inexpensive, straight forward process. While MPV levels show a correlation with platelet activation and functions, increased MPV values are related to short hemorrhage time and increased plasma thromboxane A2 level (4). In this study, the MPV was used to assess platelet functions in all cases. The in vitro parameters of p-selectin, active glycoprotein $2 b / 3 a$, platelet factor 4 and beta-thromboglobulin could not be evaluated for platelet activation and function as the study was retrospective and routine use of these parameters is very expensive.

A study by Taglieri et al. (9) reported that increased MPV levels were related to the repeated MI risk within one year. Bath et al. (10) also stated that increased MPV levels were a predictive factor for a new attack in cases with cerebrovascular disease or transient ischemic attack. The MPV level was determined to be an important biomarker for prognosis in cases with cardiovascular disease. Another study by Dogan et al. (11) reported that increased MPV values in non-ST elevation MI cases were associated with cardiac death, recurrent angina, or prolonged hospital stay. Topuz et al. (12) reported that MPV levels were higher in cases with paroxysmal AF. A study by Choudhury et al. (13) found that platelet activation and MPV levels were higher in cases with AF compared to cases with normal sinus rhythm. Ha et al. (14) also identified higher MPV values in AF cases. Erdem et al. (15) reported that preoperative MPV values were related to the risk of AF occurrence after coronary bypass. Many studies in the literature have investigated the correlation of MPV with mortality in ICU patients. Altun et al. (16) reported no correlation between MPV and mortality. A meta-analysis by Tajarernmuang et al. (17) stated no correlation between the MPV value at the time of admission to ICU and mortality. Yarkıcı et al. (18) found a significant correlation between increased MPV and mortality in intensive care. However, no previous study has evaluated the correlation between the occurrence of complications in cases monitored in the ICU and MPV. The results of the current study showed that the preoperative and postoperative MPV values in group B were significantly higher than those of group A. In group B, the postoperative MPV value was significantly increased compared to the preoperative value. The postoperative MPV value in group A was significantly increased compared to the preoperative value (Table 3 ).

In recent years, NLR has started to measure the severity of inflammation in a variety of diseases such as cardiovascular diseases, malignancy, and diabetes. The ratios of neutrophil and platelet counts to lymphocyte count have been shown to be possible markers of systemic inflammation and to be 
associated with prognosis in many cardiovascular diseases, malignancies, and chronic inflammatory diseases (19-22). Even though NLR is a marker of inflammatory conditions, it may also be responsible for renal endothelial damage and impaired microcirculation as a consequence of the inflammatory process arising from neutrophil infiltration, activated endothelium, lymphocytes, and platelets $(23,24)$. PLR has been used to predict patients' prognosis with different inflammatory and ischemic events (25). Temiz et al. (26) observed that elevated PLR was correlated with hospital mortality. In the current study, no significant differences were determined between groups A and B in respect of the preoperative and postoperative PLR values. The postoperative PLR values in groups A and B were significantly increased compared to the preoperative values. In group B, the preoperative and postoperative NLR values were significantly higher compared to those of group A. The postoperative NLR values in groups A and B were significantly increased compared to the preoperative values (Table 3 ).

Although blood parameters are now used as predictive values for many diseases and malignancies, their effect on the occurrence of complications in cases monitored in ICUs is unknown. In this study, the cases monitored in ICU were separated into two groups according to whether complications were observed or not. The blood parameters of MPV, BUN, creatinine, WBC, RBC, PLT, NLR, and PLR were evaluated and compared. In the cases with complications, the blood parameters of MPV, NLR, and PLR were observed to be higher in the postoperative period. The elevation of MPV, NLR, and PLR, especially in cases with complications, shows the role of the inflammatory response for complications. This study is important in assessing the effect of the MPV, NLR, and PLR values on postoperative complications. When the results of this study are considered, the widespread increase in MPV, NLR, and PLR values in the postoperative period may be an indicator of complications. When all cases are re-evaluated in terms of complications, taking precautions against possible complications will reduce mortality and the duration of hospital stay.

\section{Study Limitations}

Although this study provides valuable information, there are some limitations, primarily its retrospective design. Other limiting factors include the relatively low number of cases included in the study, the lack of randomization, not knowing which factors affecting blood parameters were present in cases, not knowing if cases had sudden temperature loss affecting blood parameters previously and not knowing if cases had diseases such as congenital platelet diseases. There is a need for further, randomized controlled studies with higher patient numbers to extend this topic's knowledge.

\section{Conclusion}

The occurrence of complications while cases are monitored in ICUs remains a significant problem. The prediction of complications that may occur in cases monitored in ICUs and taking rapid and effective precautions against these complications will significantly reduce mortality rates. The MPV, NLR, and PLR values of patients who had complications were observed to increase in the postoperative period. Therefore, the use of simple, rapid, and inexpensive techniques such as MPV, NLR, and PLR for the prediction of potential complications in cases monitored in ICUs will undoubtedly reduce mortality rates. statistical analysis.

\section{Ethics}

Ethics Committee Approval: Approval for the study was granted by the Hospital Ethics Committee (University of Health Sciences Turkey, İstanbul Bakırköy Dr. Sadi Konuk Training and Research Hospital Ethics Committee no: 2017-154).

Informed Consent: Retrospective study.

Peer-review: Externally peer-reviewed.

\section{Authorship Contributions}

Concept: B.B., M.Ç., D.Y., G.O.H., Design: B.B., M.Ç., D.A., B.T.Ç., G.O.H., Data Collection or Processing: B.B., M.Ç., D.Y., D.A., G.O.H., B.T.Ç., Analysis or Interpretation: D.A., D.Y., B.T.Ç., G.O.H., Literature Search: B.B., M.Ç., D.A., G.O.H., Writing: B.B., M.Ç, D.A., G.O.H., Manuscript Review and Revisation: B.B., M.Ç., D.A., D.Y.

Conflict of Interest: No conflict of interest was declared by the authors.

Financial Disclosure: The authors declared that this study received no financial support.

\section{References}

1. Vincent JL. The continuum of critical care Critical Care Vincent Critical Care 2019;23(Suppl 1):122.

2. Kristin LW, Mark S, Jesse BH. How decisions are made to admit patients to medical intensive care units: a survey of MICU directors 
at academic medical centers across the United States. Crit Care Med 2008;36(2):414-420.

3. Monica E, Thomas VP, Jean-Claude C. National questionnaire survey on what influences doctors' decisions about admission to intensive care. BMJ 2004;329(7463):425.

4. Chu SG, Becker RC, Berger PB, Bhatt DL, Eikelboom JW, Konkle $\mathrm{B}$, et al. Mean platelet volume as a predictor of cardiovascular risk: a systemic review andmeta- analysis. J Thromb Haemost 2010;8(1):148-156.

5. David RG, Anne S. Outcome of intensive care patients in a group of British intensive care units. Crit Care Med 1998;26(8):1337-1345.

6. Ertekin U, Anil O, Sabit K, Ahmet BD, Durukan AB, Tak S, et al. Mean platelet volume may predict early clinical outcome after coronary artery bypass grafting. J Cardiothorac Surg 2013;8:91.

7. Levent K, Ayça AK, Ali RA, Ağaç MT, Acar Z, Kırış A, et al. Association between mean platelet volume and coronary artery calcification in patients without overt cardiovascular disease: an observational study. Anadolu Kardiyol Derg 2012;12(1):35-39.

8. Bahar A, Aslı D, Çiğdem YG, Bölükbaşı D, Ünal EU, Koçulu R, et al. Hematological predictors and clinical outcomes in cardiac surgery. J Anesth 2016;30(5):770-778.

9. Taglieri N, Saia F, Rapezzi C, Marrozzini C, Bacchi Reggiani ML, Palmerini T, et al. Prognostic significance of mean platelet volume on admission in an unselected cohort of patients with non STsegment elevation acute coronary syndrome. Thromb Haemost 2011;106(1):132-140.

10. Bath P, Algert C, Chapman N, Neal B; PROGRESS Collaborative Group. Association of mean platelet volume with risk of stroke among 3134 individuals with history of cerebrovascular disease. Stroke 2004;35(3):622-626.

11. Dogan A, Aksoy F, Icli A, Arslan A, Varol E, Uysal BA, et al. Mean platelet volume is associated with culprit lesion severity and cardiac events in acute coronary syndromes without ST elevation. Blood Coagul Fibrinolysis 2012;23(4):324-330.

12. Topuz M, Coşgun M, Quısı A, Şen Ö, Çölkesen Y. The association between mean platelet volume and paroxysmal atrial fibrillation in patients with acute ischemic stroke. MN Kardiyoloji 2016;23(1):813.

13. Choudhury A, Chung I, Blann AD, Lip GY. Platelet surface CD62P and CD63, mean platelet volume, and soluble/platelet P-selectin as indexes of platelet function in atrial fibrillation: a comparison of "healthy control subjects" and "disease control subjects" in sinus rhythm. J Am Coll Cardiol 2007;49(19):1957-1964.

14. Ha SI, Choi DH, Ki YJ, Yang JS, Park G, Chung JW, et al. Stroke prediction using mean platelet volume in patients with atrial fibrillation. Platelets 2011;22(6):408-414.

15. Erdem K, Ayhan S, Ozturk S, Bugra O, Bozoglan O, Dursin H, et al. Usefulness of the mean platelet volume for predicting new-onset atrial fibrillation after isolated coronary artery bypass grafting. Platelets 2014;25(1):23-26.

16. Altun Y, Demircan F, Mengeloğlu FZ, Namuslu M. The relationship between mean platelet volume and mortality in patients in intensive care unit. J Clin Exp Invest 2011;2(4):408-411.

17. Tajarernmuang P, Phrommintikul A, Limsukon A, Pothirat C, Chittawatanarat $\mathrm{K}$. The role of mean platelet volume as a predictor of mortality in critically ill patients: a systematic review and metaanalysis. Crit Care Res Pract 2016;2016:4370834.

18. Yarkıcı H, Peker A, Gürlek Yıldırım S, Özalp FR, Demiral Sezer S, Akar H. Can increased mean platelet volume predict high mortality in intensive care patients? FNG Bilim Tıp Dergisi 2016;2(3):177180.

19. Demirkol S, Balta S, Kucuk U, Kucuk HO. The neutrophil lymphocyte ratio may be useful inflammatory indicator before applying other expensive and invasive procedures. Indian $\mathrm{J}$ Nephrol 2014;24(1):65-66.

20. Özsarı E, Koçak MZ. Clinical significance of mean platelet volume/ lymphocyte ratio and mean platelet volume/platelet ratio in the exacerbation of chronic obstructive pulmonary disease. Eur Res J 2019;5:1001-1006.

21. Kim NY, Chun DH, Kim SY, Kim NK, Baik SH, Hong JH, et al. Prognostic value of systemic inflammatory indices, nlr, plr, and mpv, for predicting 1-year survival of patients undergoing cytoreductive surgery with HIPEC. J Clin Med 2019;8(5):589.

22. Jaszczura M, Góra A, Grzywna-Rozenek E, Bar-Czarnecka M, Machura E. Analysis of neutrophil to lymphocyte ratio, platelet to lymphocyte ratio and mean platelet volume to platelet count ratio in children with acute stage of immunoglobulin A vasculitis and assessment of their suitability for predicting the course of the disease. Rheumatol Int 2019;39(5):869-878.

23. Kilburn DJ, Shekar K, Fraser JF. The complex relationship of extracorporeal membrane oxygenation and acute kidney injury: causation or association? Biomed Res Int 2016;2016:1094296.

24. Millar JE, Fanning JP, McDonald CI, McAuley DF, Fraser JF. The inflammatory respon-se to extracorporeal membrane oxygenation (ECMO): a review of the pathophysiology. Crit Care 2016;20(1):387.

25. Azab B, Shah N, Akerman M, McGinn Jr JT. Value of platelet/ lymphocyte ratio as a predictor of all-cause mortality after nonST-elevation myocardial infarction. J Thromb Thrombolysis 2012;34(3):326-334.

26. Temiz A, Gazi E, Güngör Ö, Barutçu A, Altun B, Bekler A, et al. Platelet/lymphocyte ratio and risk of in-hospital mortality in patients with ST elevated myocardial infarction. Med Sci Monit 2014;20:660-665. 